\title{
Assessing the Link between Petroleum Prices Hikes on Transport Fares in WA Municipality
}

\author{
Joseph Kofi Nkuah* and Eric Berko
}

School of Business and Law, University for Development Studies, WA, Ghana

\begin{abstract}
The research investigated the effects of petroleum price hikes on the transportation business in Wa Municipality. Both quantitative and qualitative research design was employed in the study. Seventy-six (76) out of eighty (80) questionnaires were received. The analysis of data was aided by the use of SPSS and Microsoft Excel. Findings from the research using linear regression models indicated that petroleum price hikes result in higher transport cost. This finding is consistent with an earlier study conducted by Ocheni. The study further revealed that increases in fuel price also triggered high cost of spare parts. The researcher recommends that government should hedge the price of fuel to mitigate the risks associated with price hikes. And also the government should subsidize the cost of spare parts, either through tax-cut or any other means possible in order to reduce the cost burden.
\end{abstract}

Keywords: Petroleum price; Hike; Transport cost; Economy; Oil; Domestic price; Energy consumption

\section{Introduction}

Hikes in petroleum prices have drawn keen attention among academics and policy makers across the globe over the years. This is as a result of its effects on output, inflation, exchange rate and the stability of the economy. Petroleum product has become an integral part of Ghanaian economy. Despite Ghana being oil producing country, the country still depends largely on imported fuel to meet her oil needs, this makes the growth of the economy vulnerable to fluctuations in the world price of oil. Hikes in the price of petroleum products in the world market are transmitted into the domestic economy through increase in the domestic prices of petroleum products in Ghana. In recent years, Ghana has experienced regular increases in the prices of Petroleum products, this affect all the sectors of the country including the transportation sector.

The transportation sector plays a significant role in national development. It serves as the back bone for the other sector for economic development. Any economic and social wellbeing depends largely on the performance of its transportation service system. Ghana's ability to achieve national targets for growth and poverty reduction will depend to a very large extent on an effective and efficient transportation system [1]. Not only does the transport business provide opportunities for the mobility of people and goods, also in the long term, it influences patterns of growth and the level of economic activity through the accessibility it provides to land [2]. It is therefore worthwhile for one to be concerned with its efficiency and effectiveness, and these are influenced by certain constant factors such as prices of spare parts, the number of vehicles running, nature of road and most especially the prices of petroleum products.

Since petroleum products serve as major energy source for the transportation sector which account for $92 \%$ of energy consumption in transport sector [3], petroleum prices hikes and its attendant consequence on the sector remain an important issue. According to Suryanto et al. [4] volatility of petroleum prices has always been global concern. Therefore, this study seeks to investigate the effects of petroleum price hikes on the transportation business in Wa Municipality of Ghana.

\section{Theoritical Issues}

The collection of theories in relation to the subject serves as a guide for the research in the determination of the relationship between the variables understudied and the adverse effect.

\section{Transport sector}

The transport business provides opportunities for the mobility of people and goods. It also influences patterns of growth and the level of economic activity through the accessibility it provides to land [2]. Transportation business is influenced by certain constant factors such as prices of spare parts, the number of vehicles running, the traffic system, nature of road and most especially the prices of petroleum products. Oil peaking will create a severe liquid fuels problem for the transportation sector, not an 'energy crisis' in the usual sense that the term has been used [5]. Since petroleum products serve as major energy source for the transportation sector which account for $92 \%$ of energy consumption in transport sector [3]. According to Jon and Richard [6] in these days of rising fuel prices and limited budgets, transportation providers are asked to ensure maximum productivity at minimum costs.

The fuel prices are a significant determinant of worldwide economic performance. The price of crude oil in global market is essentially driven by supply and demand. Other factors include; the exchange rate, taxes, oil prices [7]. Motor vehicle fuel prices have increased significantly in recent years and are likely to stay high in the future. Between 2003 and 2008 average US gasoline retail prices more than doubled, from $\$ 1.77$ to $\$ 4.10$ per gallon, and high prices are expected to continue due to growing international demand and rising production costs [8]. There

*Corresponding author: Joseph Kofi Nkuah, School of Business and Law University for Development Studies, WA, Ghana, Tel: +0244684974; E-mail: vaticanagroventures@yahoo.com

Received November 27, 2017; Accepted January 09, 2017; Published January 16, 2018

Citation: Nkuah JK, Berko E (2018) Assessing the Link between Petroleum Prices Hikes on Transport Fares in WA Municipality. J Glob Econ 6: 278. doi: 10.4172/2375-4389.1000278

Copyright: $\odot 2018$ Nkuah JK, et al. This is an open-access article distributed under the terms of the Creative Commons Attribution License, which permits unrestricted use, distribution, and reproduction in any medium, provided the original author and source are credited. 
have been several fuel price increments in Ghana recently, for instance, fuel prices increased by $11 \%$ in January, 2017, 11\% in October 2016, $27 \%$ in January 4, 2016 and 9\%-14\%, in July, 2015 respectively.

Fuel price is an emotional issue. Even when price reduces, many motorists feel they pay more than the fair. There are frequent demands for investigations into fuel price gouging, and popular campaigns to promote cheaper fuel through public policies and consumer boycotts. As a result, consumers, consumer groups and policy makers are wondering how best to respond to rising fuel prices.

The hikes in fuel price result in a transfer of income from oil consuming to oil producing countries according to a shift in terms of trade. When there is a higher oil price rise and the higher prices are maintained, it will have significant macroeconomic influence on economy. According to the net-oil exporting nations, an increase in oil price increases their real national income due to the higher export earnings. The part of this earning will be offset by losses from lesser demand for exports because of the economic downturn suffered by trading partners. By contrast, the hike in fuel prices has negative impact on oil importing countries while these countries must produce goods and services.

Due to the past oil price hikes, the total macroeconomic damage occurred, economic growth declined significantly in most oil importing nations in the two years following the price hikes of 1973-1974 and 1979-1980 [9].

\section{Relationship between transportation business and oil prices}

Oil has a lot of importance in the economy because of the dependence on it in the production of energy. In the same way, transportation sector has an effect on the economy of every nation. However, their relationship has been of a lot of concern due to their roles. In recent times, transport fares have remained unchanged despite intermittent marginal reductions in the prices of petroleum products as a result of the implementation of the petroleum deregulation policy,

Lipman [10] postulates that increased fuel prices force people to drive less, which reduces consumer surplus. Changes in mobility (the amount people travel) have various consumer impacts that should be considered in transport policy analysis. This suggests that high fuel prices burden low-income households if they lack transport options, so there are two ways to help such consumers: reduce fuel prices or improve affordable transport options available to low-income households [11]. When the price of fuel rises, it forces individual to drive less which in turn leads to high demand on commercial vehicle hence need to ensure moderate fare increment.

According to Ocheni [12] increase in fuel price results in increase in the cost of transportation. Everybody appreciates the fact that when motorists pay more for fuel, the transport fare increases. This has been the case even when the increase is only marginal. In the particular case where the cost of fuel is expected to double, the increase in transport fare will be extreme. This will in turn affect everything else; school fees, house rent, just name it.

According to Gargett and Hossain [13] at a first glance, it might seem that a hike in fuel price would pose a serious problem for transport, because there are no fuel substitutes, there is no scope for transitioning to electric or hybrid vehicles, and because rail cannot currently compete for goods that require timely delivery. However, fuel costs are only a few percent of final goods costs, so even a very large increase in fuel price would result in relatively small fares which have small flow-on costs to delivered goods.
Todd [14] opined that an increase in fuel prices result in a fall in per capita fuel consumption and vehicle travel. For instance in USA 2007 and 2008, per capita fuel consumption and vehicle travel declined, suggesting that fuel consumers are again responsive to fuel prices due to their increasing household budget impacts.

Charles [15] estimates that US short-run fuel price elasticity reached a low of -0.04 in 2004, but increased to -0.08 in 2005, -0.12 in 2006 and -0.16 in 2007. In 2007 and 2008 there have been substantial declines in the sale of fuel, inefficient vehicles such as SUVs and light trucks, indicating that consumers are taking fuel costs into account when making long-term decisions. This suggests that structural changes in consumer demands and markets have returned US fuel price elasticity to normal levels.

Anthony and Jamal [16] also noted that increase in fuel price affects the transport sector as prices will go up and also push production costs.

TEMS Inc. Technical Report [17] postulated that transport systems will adjust to fuel price increases by passing on the added costs to their customers.

In summary, researchers have investigated the relationship between the fuel price hikes and the transportation sector and its adverse effect. Almost all the literature established the fact that there is a relationship between the two variables except that some considered the effect of fuel price hikes on the transport business not to be much significant. Others found the effect to be much significant and result in high travelling cost and relatively high cost of goods delivered.

However, it is not evident enough from the empirical review (the relationship between transport business and fuel price hikes) since the population, sample design and the countries under the various researches vary. This research therefore, hopes to give an in-depth knowledge on the relationship between the petroleum price hikes and transportation business and the effect the price hikes have on the transport business in Wa Municipality.

\section{Research Approach}

\section{Research design}

Polit and Beck [18] defined research design as a general arrangement for conducting the research to enable you answer the research question. It demonstrates the steps which will be followed in conducting the research. A research design could also be considered as a "blueprint" for research which directs; which questions to study, which data are relevant, what data to collect, and how to analyze the results [19].

This study focuses on the effects of petroleum price hikes on the transportation business. Both quantitative and qualitative design was employed in the study. This is because the survey allowed us to collect quantitative and qualitative data which were analyzed. Both qualitative and quantitative approaches to research can be used in combination. Amaratunga et al. [20] explain that qualitative and quantitative researches are not mutually incompatible, rather they center on the different scopes of the same phenomenon.

According to Macer and Birks [21], qualitative research is an unstructured, primarily exploratory design based on small samples which is aimed at providing insight and understanding. Qualitative data are collected in the form of words, pictures, descriptions or narratives.

Domegan and Fleming [22] explain quantitative research as the collection of data which is open to interpretation, for instance on attitudes and opinions, and which might not be proven statistically. 
Quantitative approach involves quantifying data or assigning measures to them to statistically test them for any relationship to increase understanding of a topic. Contrary to the qualitative research, the quantitative gathers a lot of respondents.

\section{Population of the study}

Polit and Hungler [23] assert that population as an aggregate or totality of all the objects, subjects or members that conform to a set of specifications. Saunders et al. also explained population as a group of individuals, persons, objects, or items from which samples are taken for assessment [24]. The entire group of individuals about whom information is gathered is the target population. In this study the population comprised the management, conductors and the drivers of commercial vehicles in the WA Municipality, which includes bus drivers, trotro drivers, taxi drivers and drivers of the tricycle (popularly known as Mahama Kanbu).

\section{Sample size and sample techniques}

Karl [25] defined a sample as, a subset of a population selected to participate in the study, it is a fraction of the whole, selected to participate in the research project. Kumekpor [26] also stated that, sampling is the process that allows researchers to make inferences about a population based on the nature of the sample. The sample size for this study is Eighty (80) individuals. Stratified Sampling was employed to divide the population into "strata" and then simple random sampling was used to select the sample. Purposive sampling was adopted to collect data from some key staff of the GPRTU, Wa branch. The simple random sampling method gives each population an equal chance of being included in the sample.

According to Malhotra and Birks [27] stratified sampling is the separation of the population into different subgroups (strata) and then samples all these subgroups using a random sampling technique. Where population embraces a number of distinct categories, the frame can be organized into separate "strata." Each stratum is then sampled as an independent sub-population, out of which individual elements can be randomly selected. For this study, the drivers were stratified into trotro drivers, bus drivers, taxi drivers and tricycle drivers. They also defined simple random sampling as, the use of random numbers to select each individual into the sample. Purposive sampling is when the sample is chosen because they are not representative of the sample [28].

\section{Sources of data}

Data as information obtained in a course of a study [23]. The study used both primary and secondary data. Macer and Birks [21] noted that researchers should locate and analyze secondary data before collecting primary data. For this reason, the researchers first all reviewed the existing literature made up of textbooks and other materials found useful from other sources such as the internet and journals. The primary data that were used by the researchers includes data questionnaires, interviews and observation.

Macer and Birks [21] defined primary data as data originated by the researcher specifically to address the research problem.

According to Domegan and Fleming [22], secondary data are data collected by another person for reasons other than the problem in hand. In other words, secondary data is all desk researches, that is to say, the researches published by other authors. For this study, secondary data were obtained from sources such as the GPRTU-Wa Branch, DVLA-Wa Branch, NPA-website and Frimps Oil filling station.

\section{Data collection instrument}

The quality of research depends on the quality of the data collection tools. The instruments that were employed in this research were the use of questionnaires with open ended and closed ended questions and observation.

\section{Data analysis}

Data analysis refers to the process of deriving meaning from the data that had been collected in a study. According to Yin [29] the main purpose of analyzing data is to treat the evidence fairly, to produce compelling analytical conclusions and to rule out alternative interpretations.

Needed data were collected from various sources such as spare parts dealers, GPRTU while some data were downloaded from NPA website and internet. The collected data were cross checked, edited and calculated to suit the kind of data needed for this study. Microsoft Excel 2013 and SPSS version 20 were used to analyze the data and output interpreted.

\section{Hypothesis of the study}

The researcher seeks to test these hypotheses which are based on the research objectives.

\section{Hypothesis one}

Ho: Fuel Price Hikes have no effect on Lorry fares.

Ha: Fuel Price Hikes have effect on Lorry Fares.

\section{Hypothesis two}

Ho: Fuel Price Hikes have no effect on Spare Parts Cost.

Ha: Fuel Price Hikes have effect on Spare Parts Cost.

\section{Decision rule}

At 5\% significant level, reject Ho if the P-value $<0.05$.

\section{Diagnostic test}

Test of normality using Shapiro-Wilk Test [30].

\section{Model Specifications}

In order to effectively establish the effect of fuel price hikes on lorry fares and spare parts cost, the study employed descriptive analysis in a form of mean and standard deviation of the studied variables.

\section{General model specification}

The general model used to determine the effect fuel price hikes on lorry fares and on spare parts cost.

$\mathrm{Y}=\beta \mathrm{o}+\beta 1 \mathrm{X} 1+\varepsilon$

Where:

Y=Dependent Variable

$\beta \mathrm{o}=$ Equation intercept

$\beta 1=$ Coefficients of the $X$ variable

$\mathrm{X} 1=$ he Independent Variable

$\varepsilon=$ Error term 


\section{Specific regression model}

The general specified regression model was converted to the specific models needed for this study. The following regression models were run to determine the effect of fuel price hikes on lorry fares and spare parts cost.

\section{Model 1: Effects of the Fuel Price Hikes on Lorry Fares}

$\mathrm{LF}=\beta \mathrm{o}+\beta 1(\mathrm{FPH})+\varepsilon$.

\section{Model 2: Effects of the Fuel Price Hikes on Spare Parts Cost}

$\mathrm{SPC}=\beta \mathrm{o}+\beta 1(\mathrm{FPH})+\varepsilon$

Where:

$\beta \mathrm{o}=$ constant of the regression models

$\beta 1=$ Coefficient of $\mathrm{FPH}$

FPH=Fuel Price Hikes

LF=Lorry Fares

$\mathrm{SPC}=$ Spare Parts Cost

$\varepsilon=$ error term of the regression.

\section{Results and Discussion}

This section presents the findings of the study as per the specific objectives outlined in study. The findings are analyzed under four main parts. The first part considers the demographic background of the respondents, focusing on the gender, educational level and number of years in the transport business in the municipality. The second part presents the findings on the type of fuel use by the vehicles and the level of consumption per day. The next is the effects of the hikes on the transport business. Finally, the last part examines other factors that affect the transportation business in the municipality.

This research examined the effects of petroleum price hikes on the transportation business in the Wa Municipality. Specifically, it is aimed at determining the effects of petroleum price hikes on lorry fares and spare parts. It also aimed at identifying certain other factors that affect the transport business in the Municipality.

\section{Rate of response}

Out of the 80 questionnaires distributed to different sections of the respondents, $76(95 \%)$ were received. A total of sixty-five (65) questionnaires were distributed among the drivers, however sixtyfour (64) were received, (32 Tricycles, 19 Trotro, 9 Buses, 3 Taxis and 1 conductor). Also, twelve (12) out of the fifteen (15) questionnaires sent to the GPRTU staff were received. These 76 received questionnaires were verified for accuracy and consistency, the 76 questionnaires were accurate for the analysis and interpretation.

\section{Demographic characteristics of respondents}

Goll et al. [31] assert that demographic characteristics of the respondent, such as sex, age educational level, number of years spent and position in an organization give the respondent the edge to be objective, certain and comprehensive.

\section{Gender of the respondents}

From Table 1, it is observed that $67(88 \%)$ of the respondents are males whereas the remaining $9(12 \%)$ are females. This is not different from what is obtained in the secular world where more males are in paid employment than females.

Bekibele et al. [32] in a research on drivers of public institutions, in Ibadan stated that, all the respondents were males. Also, according to Asiamah et al. [33] almost all commercial drivers in Ghana are males and further stated that, female commercial drivers are rare in Ghana. This research presents same situation, as it can be observed from the Table 1 that the females constitute only $9(12 \%)$ of the respondent. This confirms the male dominance in the driving business, from the various literature.

\section{Educational level of respondents}

Asiamah et al. [33] assert that a significant number of drivers in the transport business had no formal education and most had only basic primary education. Similarly, Ipingbemi [34] noted that over $90 \%$ of drivers in the commercial transport in South Western Ibadan have no more than SHS education. On the other hand, majority of respondents with SHS and tertiary education were corporate and private drivers.

The situation does not differ with this research, Table 2 is a clear indication that the transport business is dominated by people with some level of education who constitute $61(80.3 \%)$ of the total sample, and this ranges from JHS to Degree, whereas 15 (19.7\%) of the respondents have no formal education. Those with JHS and SHS constitute a greater number of the educated people with 51 (67.1\%) of the respondents, who is dominantly drivers. Respondents with diploma and those with degree together represent $10(13.2 \%)$ of the sample, and this is largely dominated by staff of the GPRTU.

It can also be stated that just a little above $10 \%$ of the respondents have above SHS education, this corroborates with the assertion made by Ipingbemi [34].

\section{Number of years spent in the transport business in the municipality}

This represent the last aspect of the first part (the demographic characteristics), it examined the number of years a respondent has spent working in the transportation business within the Wa Municipality. The results shown in Table 3 showed that, 32 (42\%) of the respondents have spent below one (1) year in the transport business within the Municipality, followed by those who have spent from one (1) to five (5) years in the business representing 24 (32\%) of the sample and then those who have spent more than five (5) years with a percentage of 26 .

This indicates that, the transport business in the Municipality is dominated by people with less than one (1) year experience, this is largely due to the recent introduction of the tricycle (Mahama Kanbu) into the transport business which is now considered as a dominant

\begin{tabular}{|c|c|c|c|c|}
\hline & Driver & Conductor & GPRTU Staff & Total Frequency \\
\hline Male & $63(82.9 \%)$ & 0 & $4(5.3 \%)$ & 67 \\
\hline Female & 0 & $1(1.3 \%)$ & $8(10.5 \%)$ & 9 \\
\hline Total & $\mathbf{6 3}$ & $\mathbf{1}$ & $\mathbf{1 2}$ & $\mathbf{1 2}$ \\
\hline
\end{tabular}

Source: Field Survey, 2017. 
Citation: Nkuah JK, Berko E (2018) Assessing the Link between Petroleum Prices Hikes on Transport Fares in WA Municipality. J Glob Econ 6: 278. doi: $10.4172 / 2375-4389.1000278$

Page 5 of 9

\begin{tabular}{|c|c|c|c|c|}
\hline Level & Drivers & Conductors & GPRTU Staff & Total Frequency \\
\hline No Formal Education & $15(19.7 \%)$ & 0 & 0 & 15 \\
\hline JHS & $24(31.6 \%)$ & 0 & 0 & 24 \\
\hline SHS & $23(30.3 \%)$ & $1(1.3 \%)$ & $3(3.9 \%)$ & 27 \\
\hline Diploma & 0 & - & $5(6.6 \%)$ & 31.6 \\
\hline Degree & $1(1.3 \%)$ & - & $4(5.3 \%)$ & 5 \\
\hline Total & $\mathbf{6 3}$ & $\mathbf{1}$ & $\mathbf{1 2}$ & $\mathbf{7 6}$ \\
\hline
\end{tabular}

Source: Field Survey, 2017.

Table 2: Educational level of the respondents

\begin{tabular}{|c|c|c|c|c|}
\hline Experience & Drivers & Conductors & GPRTU Staff & Total Frequency \\
\hline Below 1 year & $30(39.5 \%)$ & 0 & $2(2.6 \%)$ & 32 \\
\hline 1-5 years & $17(22.4 \%)$ & $1(1.3 \%)$ & $6(7.9 \%)$ & 24 \\
\hline Above 5 years & $16(21.1 \%)$ & 0 & $4(5.3 \%)$ & 32 \\
\hline Total & $\mathbf{6 3}$ & $\mathbf{1}$ & $\mathbf{1 2}$ & 20 \\
\hline
\end{tabular}

Source: Field Survey, 2017.

Table 3: Experience in the transport business in the municipality.

\begin{tabular}{|c|c|c|c|c|c|}
\hline Fuel & Tricycle & Trotro & Bus & Taxi & Total Frequency \\
\hline Petrol & $32(50.8 \%)$ & 0 & $1(1.6 \%)$ & 33 \\
\hline Diesel & 0 & $19(30.1 \%)$ & $8(12.7 \%)$ & $1(1.6 \%)$ & 28 \\
\hline Gas & 0 & 0 & 0 & $2(3.2 \%)$ & $2 \%$ \\
\hline Total & $\mathbf{3 2}$ & $\mathbf{1 9}$ & $\mathbf{9}$ & $\mathbf{3}$ & $\mathbf{3}$ \\
\hline
\end{tabular}

Source: Field Survey, 2017.

Table 4: Type of fuel use by the vehicles.

vehicle in the transport business, ( Data from DVLA-Wa Branch) $[35,36]$.

\section{The Type of fuel Used by the Vehicles and the Level of Consumption Per day}

In this section, the researchers aimed at examining the type of fuel used by the various vehicles and their average consumption per day.

\section{Type of fuel use}

From Table 4, the research showed that, out of the sixty-three (63) responses received from the drivers, 33(52.4\%) of them use petrol, followed by diesel with $28(44.4 \%)$ and then Gas which is the least type of fuel use by the Vehicles with 2(3.2\%) of the sixty-three (63) responses from the drivers. This clearly indicates that almost all the drivers use either petrol or diesel. This study is consistent with findings by Angelo and Fiorello [37], who noted that energy sources in transport, in the European Union Nations show that about $0.16 \%$ consume gas, whereas about $96.71 \%$ consume either petrol or diesel and the remaining $3.13 \%$ use others like biofuels.

Average fuel consumption per day by the various vehicles. This section considered average fuel consumption by the various vehicles within the municipality. As shown in Table 5, a tricycle consumes GHC 50.9 of fuel which is equivalent to 13.4 litres a day. A trotro consumes GHC 65.5 of fuel a day, equivalent to 17.2 litres a day. Also, a bus consumes GHC 188.9 of fuel per day which is equivalent to 49.7 litres a day and then a taxi uses GHC 40 of fuel per day equivalent to 10.5 litres. This clearly indicates that relatively a bus consumes more fuel than the other vehicles, this is due to the fact that a bus carries heavy load and usually goes long distances. Yu et al. (2016) postulated that for fuel consumption, Passenger load has a significant influence when the vehicle is traveling at high speed above $30 \mathrm{~km} / \mathrm{h}$, while no obvious impact was observed at low speed below $30 \mathrm{~km} / \mathrm{h}$. The situation is not different from this study as the buses travel with relatively much more passengers at a very high speed.

\begin{tabular}{|c|c|c|c|}
\hline $\begin{array}{l}\text { Type of } \\
\text { Vehicle }\end{array}$ & $\begin{array}{c}\text { Various } \\
\text { Consumption Level } \\
\text { (GHC) }\end{array}$ & Number & Amount (GHC) \\
\hline \multirow[t]{7}{*}{ Tricycle } & 20 & 5 & 100 \\
\hline & 30 & 6 & 180 \\
\hline & 40 & 9 & 360 \\
\hline & 50 & 3 & 150 \\
\hline & 80 & 3 & 240 \\
\hline & 100 & 6 & 600 \\
\hline & Total & 32 & 1630 \\
\hline \multicolumn{3}{|c|}{ Average Fuel Consumption Per Day } & 50.9 \\
\hline \multirow[t]{6}{*}{ Trotro } & 45 & 5 & 225 \\
\hline & 60 & 5 & 300 \\
\hline & 70 & 5 & 350 \\
\hline & 90 & 3 & 270 \\
\hline & 100 & 1 & 100 \\
\hline & Total & 19 & 1245 \\
\hline \multicolumn{3}{|c|}{ Average Fuel Consumption Per Day } & 65.5 \\
\hline \multirow[t]{4}{*}{ Bus } & 150 & 3 & 450 \\
\hline & 200 & 5 & 1000 \\
\hline & 250 & 1 & 250 \\
\hline & Total & 9 & 1700 \\
\hline \multicolumn{3}{|c|}{ Average Fuel Consumption Per Day } & 188.9 \\
\hline \multirow[t]{4}{*}{ Taxi } & 30 & 1 & 30 \\
\hline & 40 & 1 & 40 \\
\hline & 50 & 1 & 50 \\
\hline & Total & 3 & 120 \\
\hline \multicolumn{3}{|c|}{ Average Fuel Consumption Per Day } & 40 \\
\hline
\end{tabular}

Source: Field Survey, 2017.

Table 5: Average fuel consumption per day.

Determining the effects of petroleum price hikes on the transport business in the WA municipality

This section aimed at examining whether or not there is a relationship between fuel price hikes and the transport business and the 
extent at which the hikes affect the transport business. This examination was done through the use of simple linear regression model with Lorry Fares and Spare Parts Cost as dependent variables and Fuel Price Hikes as independent variable.

\section{Test of Normality}

Normality test measures whether or not the data for the variables are normally distributed. The normality test for data of lorry fares and spare parts cost were done using Shapiro-Wilk Test which is more appropriate for small sample size $(<50)$. Hence suitable for this study since the sample size is $30<50$ as suggested by Razali and Wah [30].

Shapiro-Wilk Test was conducted under the hypothesis.

Ho: data for both lorry fares and spare parts cost are normally distributed.

Ha: Data for both lorry fares and spare parts cost are not normally distributed.

Null Hypothesis (Ho) for the test of normality is that data are normally distributed. Ho is rejected if the P-value (sig) $<0.05$, hence Alternative Hypothesis (Ha). Therefore under Shapiro-Wilk, we do not reject Null hypothesis (Ho) if P-value (sig) $>0.05$, thus data are normally distributed.

It can be observed from Table 6 that in both LF $(\mathrm{P}$-value $=0.069)$ and SPC (P-value $=0.090)$, the P-value $>0.05$, which implies that we do not reject Ho, thus data for both LF and SPC are assumed to be normally distributed.

\section{Effects of the Fuel Price Hikes on Lorry Fares}

This aspect of the chapter assesses how fuel price increases has over the years affected lorry fares. Table 7 indicates that over the years, an average increase in fuel price by $12.5 \%$ results in an average increase in lorry fares by $5.4 \%$. It can also be observed that petroleum price has over the years increased as high as $18 \%(12.46+5.56)$ and as low as $6.9 \%$ (12.46-5.56). In the case of lorry fare, it has increased as high as $7.9 \%$ $(5.4+2.5)$ and as low as $2.9 \%(5.4-2.5)$.

\begin{tabular}{|c|c|c|c|c|c|c|}
\hline & \multicolumn{2}{|c|}{ Kolmogorov-Smirnov } & \multicolumn{4}{c|}{ Shapiro-Wilk } \\
\cline { 2 - 7 } & Statistic & df & Sig. & Statistic & df & Sig. \\
\hline LF & 0.134 & 30 & 0.18 & 0.936 & 30 & 0.069 \\
\hline SPC & 0.128 & 30 & 0.2 & 0.94 & 30 & 0.09 \\
\hline
\end{tabular}

Source: Field Survey, 2017.

Table 6: Tests of normality.

\begin{tabular}{|c|c|c|c|}
\hline \multicolumn{4}{|c|}{ Descriptive Statistics } \\
\hline & Mean & Std. Deviation & $\mathrm{N}$ \\
\hline LF & 5.3667 & 2.51181 & 30 \\
\hline FPH & 12.4667 & 5.56921 & 30 \\
\hline Correlations & - & LF & FPH \\
\hline Pearson Correlation & LF & 1.000 & 0.906 \\
\cline { 2 - 4 } & FPH & 0.906 & 1.000 \\
\hline R-Square & 0.821 & - & - \\
\hline Std Error & 0.89266 & - & - \\
\hline Anova & F & Sig (P-value) & - \\
\cline { 2 - 4 } & 152.589 & 0.000 & - \\
\hline Regression Model & $\beta$ & t- Value & Sig (P-Value) \\
\hline Constant & 1.155 & 2.850 & 0.008 \\
\hline FPH & 0.338 & 11.350 & 0.000 \\
\hline
\end{tabular}

Source: Field Survey, 2017.

Table 7: Regression results of FPH \& LF.

\section{The Correlation}

The strength of the relationship between FPH and LF was measured using correlation coefficient. Correlation measures the extent of relationship between the independent variable (FPH) and the Dependent variable (LF). Correlation coefficients generally take values between -1 and +1 . A Coefficient $>0.5$ indicates a strong positive relationship. From Table 7 , it is indicted that there is very strong positive relationship between FPH and LF, as it has a value of $0.906>0.50$ as suggested by Evans (1996).

\section{The R-Square $\left(\boldsymbol{R}^{2}\right)$}

The $R^{2}$ measures the changes in the dependent variable (LF) caused by changes in the independent variable (FPH). It can be observed from Table 7 that $R^{2}$ is $0.82(82 \%)$. This indicates that an $82 \%$ variation in LF is caused by variation in FPH, which implies that FPH has significant influence on LF.

Table 7 contains the results of the linear regression model with Fuel Price Hikes (FPH) as independent variable and Lorry Fares (LF) as dependent variable. The independent variable FPH had T-value of 11.350, P-value of 0.00 depicting that FPH variable is significant since $\mathrm{P}$-value $0.00<0.05$. The $\mathrm{F}$ value of 152.589 with $\mathrm{P}$-value of $0.000<0.05$ implied that the overall model is significant at $5 \%$ level. This further indicates that FPH has effect on LF. The effects of FPH on LF is positive, for instance FPH coefficient of 0.338 implied that $1 \%$ increase in $\mathrm{FPH}$ leads $0.338 \%$ increase in lorry fare.

This finding is consistent with the study by Ocheni [12] who noted that increase in fuel price results in increase in the cost of transportation. It further stated that in the particular case where the cost of fuel is expected to double, the increase in lorry fare will be extreme. This will in turn affect everything else; school fees, house rent, among others. Anthony and Jamal [16] also noted that increase in fuel price affects the transport sector as prices will go up and also push production costs. Transport systems will adjust to fuel price increases by adding the extra costs to their customers, (TEMS Inc. Technical Report 2008) [17].

\section{$\mathrm{LF}=\beta \mathrm{o}+\beta 1(\mathrm{FPH})+\varepsilon$ \\ The model is specified below}

$\mathrm{LF}=1.155+0.338(\mathrm{FPH})+\varepsilon$.

\section{Effects of the Fuel Price Hikes on Spare Parts Cost}

This aspect of the chapter assesses how fuel price increases has over the years affected spare parts cost. Table 8 indicates that, over the years,

\begin{tabular}{|c|c|c|c|}
\hline \multicolumn{4}{|c|}{ Descriptive Statistics } \\
\hline & Mean & Std. Deviation & $\mathrm{N}$ \\
\hline SPC & 4.9333 & 1.83704 & 30 \\
\hline FPH & 12.4667 & 5.56921 & 30 \\
\hline Correlations & - & SPC & FPH \\
\hline Pearson Correlation & SPC & 1.000 & 0.812 \\
\cline { 2 - 4 } & FPH & 0.812 & 1.000 \\
\hline R-Square & 0.659 & - & - \\
\hline Std Error & 1.09103 & - & - \\
\hline Anova & $\mathrm{F}$ & Sig (P-value) & - \\
\hline \multirow{2}{*}{ Regression Model } & 54.217 & 0.000 & - \\
\hline Constant & $\beta$ & t- Value & Sig (P-Value) \\
\hline FPH & 1.594 & 3.218 & 0.008 \\
\hline
\end{tabular}

Source: Field Survey, 2017.

Table 8: Regression results FPH \& SPC. 
an average increase in fuel price by $12.5 \%$ results in an average increase in spare parts cost by $4.9 \%$. It can also be observed that petroleum price has over the years increased as high as $18 \%(12.46+5.56)$ and as low as $6.9 \%(12.46-5.56)$. In the case of spare parts cost, it has increased as high as $6.7 \%(4.9+1.8)$ and as low as $3.1 \%(4.9-1.8)$.

\section{The correlation}

The strength of the relationship between FPH and SPC was measured using correlation coefficient. Correlation measures the extent of relationship between the independent variable (FPH) and the Dependent variable (SPC). A Coefficient $>0.5$ indicates a strong positive relationship. Table 8 indicates that there is a strong positive relationship between FPH and SPC, as it has a value of $0.812>0.50$, as suggested by Evans (1996).

\section{The R-Square $\left(R^{2}\right)$}

The $R^{2}$ measures the changes in the dependent variable (SPC) caused by changes in the independent Variable (FPH). It can be observed from Table 8 that $R^{2}$ is $0.66(66 \%)$. This indicates that $66 \%$ variation in SPC is caused by variation in FPH, which implies that FPH has significant influence on SPC [38].

Table 8 contains the results of the linear regression model with Fuel Price Hikes (FPH) as independent variable and Spare Parts Cost (SPC) as dependent variable. The independent variable had T-value 7.363 , $\mathrm{P}$-value, 0.00 depicting that FPH variable is significant since P-value $0.00<0.05$. The F-value of 54.217 with $\mathrm{P}$-value $0.000<0.05$ implied that the overall model is significant at $5 \%$. This further indicates that $\mathrm{FPH}$ affects SPC. The effects of FPH on SPC is positive, for instance FPH coefficient of 0.268 implied that $1 \%$ hike in fuel price results in $0.27 \%$ increase in Spare Parts Cost.

$$
\mathrm{SPC}=\beta \mathrm{O}+\beta 1(\mathrm{FPH})+\varepsilon
$$

The model is specified below

$$
\mathrm{SPC}=1.594+0.268(\mathrm{FPH})+\varepsilon
$$

Where:

\section{Std. Deviation $=$ Standard Deviation}

\section{Std. Error=Standard Error}

FPH=Fuel Price Hike

$$
\begin{aligned}
& \mathrm{LF}=\text { Lorry Fare } \\
& \text { SPC=Spare Parts Cost. }
\end{aligned}
$$

\section{Other Factors that Affect the Transport Business in the Municipality}

The last part of the chapter examines other factors, aside the fuel price hikes, which have the potential to affect the transport business in the Municipality. This section examines how factors such as; acquisition of roadworthy certificate, acquisition of vehicle insurance packages, vehicle income tax, cost of spare parts, the road network; and other factors serve as a challenge to business in the Municipality.

\section{Acquisition of roadworthy certificate}

From Table 9, out of the 31 drivers who require roadworthy certificate as a requirement for the registration of the vehicle, 21

\begin{tabular}{|c|c|c|c|}
\hline Factor & Response & Frequency & Percent \\
\hline \multirow{3}{*}{$\begin{array}{l}\text { Acquisition of Roadworthy } \\
\text { Certificate is a challenge }\end{array}$} & Agree & 22 & 71 \\
\hline & Disagree & 9 & 29 \\
\hline & Total & 31 & 100 \\
\hline \multirow{3}{*}{$\begin{array}{c}\text { Acquisition of Vehicle } \\
\text { Insurance Package is a } \\
\text { challenge }\end{array}$} & Agree & 23 & 74 \\
\hline & Disagree & 8 & 26 \\
\hline & Total & 31 & 100 \\
\hline \multirow{3}{*}{$\begin{array}{c}\text { Payment of Vehicle } \\
\text { Income Tax is a challenge }\end{array}$} & Agree & 20 & 64.5 \\
\hline & Disagree & 11 & 35.5 \\
\hline & Total & 31 & 100 \\
\hline \multirow{3}{*}{$\begin{array}{c}\text { Cost of Spare Parts is a } \\
\text { challenge }\end{array}$} & Agree & 70 & 92 \\
\hline & Disagree & 6 & 8 \\
\hline & Total & 76 & 100 \\
\hline \multirow{3}{*}{$\begin{array}{l}\text { Nature of the Road } \\
\text { Network }\end{array}$} & Bad & 18 & 24 \\
\hline & Good & 58 & 76 \\
\hline & Total & 76 & 100 \\
\hline
\end{tabular}
(71\%) said the certificate is a challenge to the business in terms of the cost involved in getting the certificate and the process of acquiring the certificate whereas 9 (29\%) believe that is it not a challenge. This
Source: Field Survey, 2017.

Table 9: Other factors that affect the transport business.

is a clear indication that acquisition of roadworthy certificate is a challenge to the transport business in the Municipality. Suryanto et al. [4] postulated that drivers in Hong Kong wait two months to get their vehicle roadworthy certificates.

\section{Vehicle insurance package}

Vehicle Insurance (also known Car, Motor or Auto Insurance), is a financial protection of one's vehicles against physical damage bodily injury from accident. Table 9 clearly indicates that acquisition of vehicles insurance packages is a challenge, $23(74 \%)$ of the respondents agreed that it is a challenge to the business, the reason being that it is expensive especially the recommended one (Third Party Vehicle Insurance) and also, in the case of accident, it is very difficult to receive the compensation [39].

On the question of vehicle income tax as a challenge to the transport business, $20(64.5 \%)$ of the respondent agreed that it poses a challenge because it reduces their return, Whereas 11 (35.5\%) of the respondents disagreed that it is challenge, as they consider it as citizenry responsibility.

This depicts that payment of vehicle income tax is a challenge to the drivers in the transport business in the Municipality. This situation is not different from a study by ATRI which noted that government regulations such duty on drivers is ranked the $4^{\text {th }}$ challenge for transport business.

Looking at spare part cost, it is one major item that drivers consider when taking decision regarding the transport business. Table 9 clearly shows that cost of spare parts is a major concern to drivers as $70(92.1 \%)$ of respondents agreed to the fact that high cost of spare parts is a major challenge, with 6 out of 76 respondents consider cost of spare parts as not a challenge to the business.

This implies that cost of spare parts is a major challenge to the transport business.

When respondents were asked about the nature of the road network, 58 (76\%) of the 76 respondents consider the road as "good one" whereas the remaining 18 (24\%) consider the road as "bad one" with the view that there are too much speed ramps and a lot of patches on the road.

\section{Other challenges noted by the respondents}

As part of the questionnaire, respondents were asked to identify 
other challenges which were specifically asked in the questionnaire. Various challenges were stated, the major ones includes.

\section{Poor driver passenger relationship}

About 31 (49\%) out of the 63 drivers stated that there is a poor relationship between drivers and passengers (majority being students) most especially in the season where lorry fares are increased.

\section{No parking place and "Bus stop" for the vehicles}

About 14 (22\%) of the drivers assert that due to lack of appropriate parking place for the vehicles, vehicles park carelessly which is very dangerous, and sometimes lead to accident. They also mentioned "Bus Stop" for the vehicles, especially those doing town running are not available.

\section{Careless driving among the motorcycle riders}

As part of the findings, it was revealed that careless driving by motorists is one of the challenges faced the transport business in the Municipality.

\section{Conclusion}

\section{Findings of the study}

The findings revealed that the transport business is dominated by males and also more than $80 \%$ of the respondents have some level of Education.

From the regression analysis, the $R^{2}$ in both model 1 and model 2, it was revealed that a higher percentage of $82 \%$ and $66 \%$ variation in the LF and SPC respectively is explained by variation in FPH. It also established that the effects of FPH on both LF and SPC is positive, where a $1 \%$ increase in Fuel price results in an increase of $0.34 \%$ and $0.26 \%$ in LF and SPC respectively. And both significant at $5 \%$ level of significant which depicts a $95 \%$ confident level.

Considering the other factors that affect the transport business, the study revealed that majority (ranging from 65\% to 92\%) of the respondents indicated that factors such as vehicle income tax, acquisition of roadworthy certificate, acquisition of vehicle insurance packages and the cost of spare parts are challenges to the transport business in the Municipality.

The study also discovered that $58(76 \%)$ of the respondents noted that the road network is good, though some stated that there are too many speed ramps and patches on the roads. Lastly, some respondents indicated some other challenges such as; No parking place and "Bus stop" for the vehicles, poor driver passenger relationship, careless driving by the motorists and also the lorry station is too small.

\section{Conclusion}

Based on the various findings of the research, it can be concluded that hikes in petroleum price result in higher transport cost.

It can also be stated that increase in fuel prices lead to increase in cost of spare parts for drivers.

The transport business within the Municipality is faced with certain challenges such as acquisition of roadworthy certificate, acquisition of vehicle insurance packages, and high cost of vehicle income tax, careless motorcycle riding, small station lorry station, poor driver passenger relationship and high cost of spare parts.

\section{Recommendation}

The transport business like many businesses, depends largely on petroleum products as a source of energy, therefore when prices of fuel increase, the usage of fuel becomes costly, the business saves less, as much would be needed to buy the same amount of fuel. The researchers recommend that the Government should hedge the price of fuel in order to reduce the related risks associated with increase in fuel price.

And also subsidize the cost of spare parts, either through tax-cut or any other means possible.

The study also found that there is usually a driver passenger conflict over fares when there is fuel price hikes with corresponding lorry fare increment, therefore there is the need for National Media Commission, the GPRTU and any other stakeholder involved to educate the public on any lorry fare increment.

There is also the need to enhance the education and regulations on motorists.

The government should all reduce the price of vehicle income tax. And also a new lorry station should be constructed or expansion of the existing one is recommended.

It is also recommended that future researchers should examine the impact of the Introduction of the tricycle (Mahama Kanbu) on the trotro business in the Municipality.

\section{References}

1. Ghana Transport Sector Review Report (2009, 2010).

2. Dimitriou HY (2001) Urban Transport Transportation Planning

3. Armah B (2003) Economic Analysis of the Energy Sector. Accra: Ghana Energy Commision.

4. Suryanto, Kuncoro M, Sartohadi J (2012) physical characteristics and disaste risk perception correlation at Bantul regency. Economics Journal of Emerging Market. 4: 1-11.

5. Edward GJ (2005) Peaking of world oil production. Department of Energy.

6. Jon EB, Richard G (2012) Sharing the Costs of Human Services Transportation Transportation Research Board, Washington 2277: 57-64.

7. Dawie Roodt (2016) 3 Reasons for the Petrol Price Hike (and why it will hurt more than you think)

8. James KJ (2006) U.S. Trade Deficit and the Impact of Rising Oil Prices. Congressional Research Service, Report for Congress.

9. Teresa TM, Mark A, Simon J (2008) Food and Fuel prices, Recent Developments macroeconomic impact, and Policy Responses. IMF.

10. Lipman BJ (2006) A Heavy Load: The Combined Housing and Transportation Burdens of Working Families. Center for Housing Policy.

11. Aaron G (2010) Welfare and Equity Impacts of Gasoline Price Changes under Different Public Transportation. Journal of Public Transportation 13: 1-21.

12. Ocheni SI (2015) Impact of Fuel Price Increase on the Nigerian Economy. Mediterranean Journal of Social Sciences.

13. Gargett D, Hossain A (2008) BITRE Briefing: How do fuel use and emission respond to price changes? Bureau of Infrastructure, Transport and Regional Economics.

14. Todd L (2011) Changing Vehicle Travel Price Sensitivities: The Rebounding Rebound Effect. Transport Policy.

15. Charles K (2008) We Explain Gasoline Demand (including why it's sticky). Carbon Tax.

16. Anthony A, Jamal M (2014) Fuel Price Adjustments and Growth of SMEs in the New Juaben Municipality, Ghana. International Journal of Small Business and Entrepreneurship Research 22: 13-23.

17. Transportation Economics \& Management Systems. The impact of oil prices 
Citation: Nkuah JK, Berko E (2018) Assessing the Link between Petroleum Prices Hikes on Transport Fares in WA Municipality. J Glob Econ 6: 278. doi: $10.4172 / 2375-4389.1000278$

Page 9 of 9

on U.S. domestic freight transportation. (TEMS Inc. Technical Report October, 2008).

18. Polit DF, Beck CT (2018) Essentials of Nursing Research: appraising evidence for nursing practice. Philadelphia: Wolters Kluwer Health.

19. Ader HJ, Mellenbergh GJ, Hand DJ (2008) Advising on research methods: A consultant's companion. Psychologische Methodenleer.

20. Amaratunga D, Baldry D, Sarshar M, Newton R (2002) Quantitative and qualitative research in the built environment: Application of "mixed" research approach. Work Study 51: 117-131.

21. Macer T, Birks DF (2007) Marketing Research: an applied Approach. 3rd European Edition. England: Prentice Hall.

22. Domegan C, Fleming D (2007) Marketing Research in Ireland: Theory and Practice. (3rd edn). Dublin: Gill \& MacMillan

23. Polit DF, Hungler BP (1999) Nursing Research: Principles and Methods 6th ed. Philadelphia: J.B. Lippincott.

24. Saunders M, Lewis $P$, Thornhill A (2007) Research methods for business students $\left(4^{\text {th }} e d n\right)$. Harlow: Pearson Education.

25. Karl LW (1996) Straightforward Statistics for the Behavioural Sciences. Journal of the American Statistical Association.

26. Kumekpor TKB (2002) research Method and Techniques of Social Research, Son life.

27. Malhotra NM, Birks DB (2008) Marketing Research: An Applied Approach. London, Prentice Hall.

28. Palys T (2003) Research decisions: quantitative and qualitative perspective. Toronto, Canada.
29. Yin R (2003) Case Study Research Design and Methods second and third edition.

30. Razali NM, Wah YB (2011) Power of comparisons of Shapiro-wilk, Kolmogorovsmirnov, lilliefors and Anderson-Darling tests. Journal of Statistical Modelling and Analytics 2: 21-33.

31. Goll I, Johnson NB, Rasheed AA (2008) Top management team demographic characteristics,business strategy, and firm performance in the US airline industry: The role of managerial discretion. Management Decision, 46: 201-222.

32. Bekibele CO, Fawole OI, Bamgboye AE, Adekunle LV, Ajayi R, et al. (2007) Prevalence of refractive errors and Attitude to spectacle use among drivers of public institutions in Ibadan, Nigeria. Annals of African Medicine 6: 26-30.

33. Asiamah G, Mock C, Blantari J (2002) Understanding the knowledge and attitudes of commercial drivers in Ghana regarding alcohol impaired driving. Injury Prevention 8: 53-56.

34. Ipingbemi $O$ (2010) Travel Characteristics and Mobility Constraints of the Elderly in Ibadan, Nigeria. Journal of Transport Geography 18: 285-291.

35. Fosu AK, Aryeetey E (2008) 3 Ghana's Post Indepentical Perspectives on Stabdence Economic Growth, 1960-2000. Boydell \& Brewer, pp: 36-77.

36. Kabur R (2008) The Economy of Ghana: Analytical Perspectives on Stability, Growth \& Poverty. James Currey, pp: 36-77.

37. Angelo G, Fiorello (2009) The Impact of Oil Prices Fluctuations on Transport and its related Sectors. Policy Department Structural and Cohesion PoliciesTransport and Tourism.

38. American Transportation Research Institute (ATRI) Report (2008). Critical Issues in the Trucking Industry.

39. CERA (2006) Gasoline and the American People, Cambridge Energy Research Associates. 